\title{
Gagauzian onomastics: Mapping cultural hallmarks through names, surnames and Orthodoxy
}

\author{
MitranIlie Iulian ${ }^{1}$ \\ Doctoral School of Sociology, University of Bucharest
}

\begin{abstract}
Gagauzian onomastics presents us an intrequit structure which is characterized by various lingusitic layers that overlap, or at times, even blend in with each other. Unlike other Turcik groups, the Gagauzians pride themselves with their strong commitment to the Orthodox Church. Lexical layering is a defining characteristic of Gagauzian onomastics.As a result, the names and surnames that are found among these people are were, to a certain exctent, transfered from the those groups that they heavly interacted with until the present. The layered layout of Gagauzian onomastics refects the different stage of the coming into being of this peoples, taking this in to consideration, it is important to note that certain surnames are of older date than others, this being the case of those that are of Greek origin. Nowadays, in Moldova, the state with the largest Gagauzian communities, first names are of Russian origin, and are directliany linked to strong russofilia that is present within Gagauz communities beginning with the second falf of the last century. The data that was used for this paper was collected from various soruces - scientific papers, journals, annals etc. Within this paper we are attempting to highlight the conservative character of Gagauzian name-giving practices and the way in which this corelates to the virtues that are central to these peoples.

Keywords; Mapping cultural hallmarks, Gagauzian onomastics, Orthodoxy, and Turcik groups
\end{abstract}

\section{From Cavarna to the desolate plains of Budjak: Key-events that shaped Gagauzian history and culture}

Just a few years ago, Congaz, a settlement in southern Moldova, was roomered to be benefinitng from a series of privileges, which were made possible through the good will of some high-ranking politicians from Kishinev. More exactly, the local church from Congaz, which was recently reabilitated through the direct implication of numerous parishioners, was exonerated from any type of taxation for the new bells that were manufactured abroad. The members of the local community were delighted by the ,gift” that was grated by the seemingly pios politicians, even so the action was brutally criticized by others which acussed the ones that backed up this initiative as encouraging the use of double standards. My desire to introduce this story in the first lines of this paper is no coincidence, in fact it can facilitate a clear understanding of the role that the local parish plays in the day-to-day life of the Gagauzian communities that are scattered across southern Moldova and Ukraine's Budjeak region. Having Eastern Ryte Christianity deeply rooted within families, and communities, the Gagauzians develop an onomastics that merges two antagonical elements - one one had we have the firs/middle names which are collected from a pan-Orthodox cultural realm- names that honor Byznatine saints, spiritual virtues - ethimologically we can trace their roots back to Greek, Hebrew, or various Slavic language; the second element is represented by the surnames, unlike the first mentioned, this one is more static, and mainly gives references to aspects of lay life -traditional professions being well represented. Even so, surnames can be altered to a certain extent, this being often corellated with identity policies - Gagauzian ${ }^{2}$ surnames being targeted by such policies which were put in to action after the

${ }^{1}$ Doctoral School of Sociology, University of Bucharest

E-mail: mitraniulian@euorpemail.com

Phone: +40724099097

${ }^{2}$ Gagauz/Gagauzian - ethnonym used to refer to a member of a Turkic group that is primarily found in the north-eastern corner of the Balkan Peninsula and Southern Moldova that adhere to Orthodox Christianity. Gagauzian may be use when referring to a member of the actual ethnic group, while Gagauzian can be used to generally refer to an inhabitant of GagauzianAutonomous Territory, regardless of his or her ethnic background.

Turkic- language family that is spread throughout Central Asia, the Northern Caucasus, Siberia, Anatolia, and the Balkans. Also referring the nations that are part of this language family.

Paternal/maternal lineage - traits inherited from the father's/mother's side of the family.

Folk-Orthodoxy - rituals that are directly, or loosely, linked to various traditions of the Orthodox Church. In fact, they represent reinterpreted versions of Church rituals and traditions, from a rudimentary understanding that is characteristic 
annexation of Besserabia, in 1812 (Măcris, 1999). In order to present a balanced perspective on the changes that accured to Gagauzian surnames over the nine decades, I relied on resources which listed numerous prominent Gagauzian local figures dating back to the 1930s, up to the present-day. Unlike first/middle names, the surnames preserved fragments of turcik and Greek lexicon, the later one being traced back to what we know now as the Cavarna Era.

Writings from the beginning of the XX century give us a glimpse on the way in which Gagauzians were perceived by outsiders, and the role that they played in the wider society. It is important to point out that many of these writings, which in fact are based on sources that we can trace back one century earlier, indicated that Gagauzians were fairly well integrated within the villages and towns in which they had their households (Măcriş, 2000). There is no specific data that could suggest to us that the vast majority of Gagauzians were clustered within a single social or economic class, we are inclined to think that the members of this community were scattered across various social layers present at a given time. Even so, we have reliable sources that show us that there were a few very prominent families, most noteworthy is the Cartagi family, which traces its lineage to Wallachia, Moldavia, Poland and Russia. Old manuscripts from the National Archives from Bucharest show us the privileged social status that some Gagauzian families had in Bessarabia. The Cavalioti family owned about 1200 hectares of land at what was known as Tiganca domain, located in Cahul County. During the agricultural reform that began in1921, the Cavaliotis made a petition stating that they were unhappy in regard to the money that they received as compensation for the lands that were taken away from them by the State.

Byzantine-rite Christianity found fertile ground within Cavarna due to the presence of the Gagauzians, documents show that during the XIV century the town was almost entirely made up by Christians. Balchik also was regarded as a major center of Christian life during the same period in Southern Dobrudja. Besides this, the town also acted as a maritime trading, some sources stating that the town's dwellers were enjoying numerous amenities that were not so common during that period. Yet again, this is not something uncommon when it comes to settlements that had their economy heavily reliant of trade. A quick review of the works of Romanian scholars that studied the Gagauzians at the beginning of the XX century shows that there was a strong general consensus that this group was descendent from the Oghuz tribes. The following statement, made by ŞtefanCioban, member of the Romanian Academy, argues that „The Gagauzians constitute the one minority from Bessarabia that closely follow the Romanians through their spirituality and gentleness (Măcriș, 2007). All the Gagauzians have a high proficiency in Romanian”. In the between war period, many surveys highlighted the fact that these people had a very high proficiency in Romanian, in fact being, as some sources state, the single minority group in which you won't find people that have no knowledge of the state's national language. Some reasons that backup this claim is the fact that Gagauzian and Romanian have a few common traits that made the language easy to assimilate. First of all, both share a few similar sounds (e.g. î/â [ro] - I [gz/tr], ş [ro] - ş [gz/tr], ă [ro] - ê [gz/tr], ci [ro] - ç [gz/tr], ge [ro - c [gztr]). Both Romanian and Gagauzian are phonetic languages, meaning that, most often, each sound corresponds to a specific letter; and there is a limited segment of vocabulary that is common to both Gagauz and Romanian, this is due mainly to the fact that Romanian contains numerous loan words from several Turcik languages - Cuman, Turkish, Tatar. These words can also be found in Gagauzian, even though sometimes their meaning can be a little bit more nuanced.

In order to facilitate a better understanding of the particularities that certain naming systems have, we must acknowledge that there is a particular relation between dominating groups, those that were the founders of regional powers, or empires, and groups that had a history that didn't give the ideal setup for the creation of a vernacular system of judicial norms and institutions. More precisely, the groups that fall in the latter category, weakly developed, mainly inhabiting lands that were always under foreign domination, usually have a tendency to borrow surnames from the occupant-group. Usually weaker groups, in some situations, are forcefully assimilated, or there is an attempt to do so, one of the stages of this lengthy process concerns the adoption of names, from a determined set sometimes, that are more in tune with the culture of the occupant-group. This serves many times an administrative purpose, in multi-national empires, a more

to rural communities, mainly due to a lack of former religious educations among peasants. They are often mixed with pre-Christian elements which makes Folk-Orthodoxy highly eclectic in nature.

ethno-religious group - ethnic group in which identity and religious affiliation are interblended to the point in which there is not clear demarcation between the two.

Budjak- the southern part of Bessarabia, that stretches along the Black Sea coast from the Kylia Branch to the Dniester lagoon. 
homogenous set of given-names and surnames can prevent potential mistakes through the misspelling of those names which come from a language that uses a different script, or set of sounds, than the official language. Besides aspects that are related more to the pragmatic aspects, there are also factors that are more strongly linked to nationalistic ideals, through the narrowing of the possible set of given names and surnames that can be used can create the illusion of a more ethnically homogenous state (Iulian, 2017), or the creation of an umbrella-culture that can lead slowly to the assimilation of various ethnic minorities (Aydin \& Damgaci, 2017; Damgaci \& Aydin, 2014) . Even so, it is interesting to note that usually there is a set of surnames that have a low frequency among minorities, we are talking specifically about those names that usually constitute the "onomastic core" of the dominant group, those surnames that are usually regarded as being the most representative e.g. Russian: Ivanov, Romanian: Popescu, Popa.

Another technique that is used is that of just attaching a specific suffix to an already existing surname, mostly we are talking here about patronymic suffixes: e.g. Ahmed/Ahmedov,Curudim/Curudimov. This was especially the case with those surnames that did not have a vernacular patronymic suffix already attached to them. If this was already the case, sometimes the original surname is translated, if possible. We can point out that there is a set of surnames that are present in multiple languages in an almost identical form, usually these surnames make reference to traditional professions: e.g. Morar/Moraru (Romanian) - Melnik (Ukrainian) - Miller (English) - Müller (German); Cioban/Ciobanu (Romanian) - Çıban (Gagauz), Croitoru (Romanian) - Schneider (German) - Taylor/Tailor (English), Fieraru/Feraru (Romanian) - Smith (English). In the case of the Gagauzians, certain Slavic surnames started to increase in number in period that followed the colonization in Bessarabia (Duminică, 2016). These surnames could actually trace their origin to mixed marriages with the Bulgarians, we need to take into account that Gagauzians and Bulgarians established mixed settlements among the valley of the Iaplug river. The period which followed the settlement in this region, prior inhabited by Nagoi Tatars, was marked by a strong interethnic bond the two groups. After the period of privileges granted by the Russian Empire ended, some Gagauzians and Bulgarians moved back to Dobrudja, some of the elderly of VamaVeche actually are descendents of those that came back to the motherland due to the rapid degradation of living standards in southern Bessarabia.

Dramatic changes occurred within the self-consciousness of this group in the post-colonization era. And interesting aspect that should be analyzed more in depth is the way in which the Gagauz groups from present-day Moldova managed to preserve, and even to glorify (Duminică, 2017), their ancestral affiliation with the Turcik Commonwealth, in their attempt to resist assimilation, and the paradox that is constituted by the Bulgarian identity that was adopted beginning with the last few decades of the last centuries by the Gagauzians that are still living in the Cavarnian homeland.

Travel journals from the early 1900s depict Cavarna as a settlement with an ambiguous ethnic profile, where Gagauzians represented on town's main communities. The strong bond between Gagauzians, Romanian, Bulgarians and Greeks cannot be denied, this was mainly maintained by the fact that all four groups were practicing Orthodox Christianity, this providing a common ground for cultural exchange between them. During the latter half of the XIX century documents show us that prior to the end of the Ottoman rule in Bulgaria, parish life and religious services were deeply influenced by the costumes of the Greek community, as a result, in throughout this epoch the Gagauzians acquired some cultural costumes from the Greeks. There are several surnames that we can trace back to this period - Mavrogheni, Cartagi, Caranfil e.g.; it should also be taken into account that Greek acted as a sort of lingua franca among the Christians living in the area. After Bulgaria was reestablished as an independent state, the Bulgarian influence started to increase in the region. This should also be attributed to the policies that were carried out with the goal of weakening the Muslim community. The sources that are available don't point any history of ethnic unrest between the Gagauzians and other communities, first-hand witness reports state that there was a relative feeling of harmony between the people of Cavarna. "Sitting on a chair, just outside of Alexe's coffee shop, stands a Gagauz that talks with a Bulgarian, both of them are counting the beads from a string" this is how a casual social setting from Cavarna is described by a traveler at the beginning of the XX century (Măcriș, 1999).

The historical documents, and ethnographic data, that are available show us that the Gagauzians had a stronger bound with the Greeks and Romanians, than they had with the Bulgarians. During the period in which most Gagauzians were still living in their ancestral towns and villages that were cramped in the Mangalia-Cavarna area, mostly before the end of the XVIII century, they were members of local Greek parishes, thus the religious services were also done in Greek (Baş, 2015). The Gagauzians tried as much as they could to stay away from the influence of the Bulgarians, by attending Greek churches they were under the direct supervision of the Patriarch of Constantinopole. 
There are also testomonies from travelers that give us solid proof vlachophilia and grecophilia had many partizans among the Dobrudjan Gagauzians, even though nowadays many old simpathies had faded away, many Moldovan Gagauzians still retain surnames that remind of their ancestor's close ties with the Romanians: Vlah - literary meaning Vlach, an old exonim for the Romance-speaking of Eastern Europe, is a surname that can be found among the Moldovan Gagauzians. Irina Vlah, the first woman that serves as the bashkan of Gagaziua, has both Gagauz (paternal) and Bulgarian (maternal) ancestry. It is crucially important to mention that for this study were selected only those names that we had clear information that were of Moldovan, Romanian and Ukrainian citizens that were not of mixed descendance, or if this was the case, they should have Gagauz ancestry from the paternal side. This way, it is more easy to keep track of the transfer ot surnames through the generations. For those that are of mixed acenstry, and inherite their Gagauz ancestry from the maternal side, will be denefently harder to get information about their mother's maiden name, if otherwise it is not specifically mentioned in the documents that we are using (Haines, 2016).

The surnames that are listed in the following tables belong to different local figures from Gagauzia that had a significant contribution to the development of the communities in which they resided, their efforts made a remarkable difference in the development of the local school system, craftsmanship, commerce and religious life.

\section{Methodology}

From a methodological perspective, this paper exlusively relied on data gathered from a variety of sources, mainly being extracted from various documents which contained names of local figures which played a major, or somewhat important, role in the national awakening of the Gagauzians. The names that came to be used come were those of people that were known to have both paternal and maternal Gagauzian ancestry, people of mixed background were excluded. Also, we are not talking about a quantitative study, as the data is too scarce and it is impossible to map any sort of patterns with them. On the other hand, the data, and the manner in which it is presented, is revevant in a widder context which deals with creating a

knowledge archive of the socio-lingusitics profiles of the Balkan Turks. To a certain extent, from various demographic documents, files concerning local history, and administrative documents from Budjack (Southern Moldova) is hard to determine one's ethnic background just by looking at a name, as centuries of living in mixed communities passed various Bulgarian and Greek, and latter Russian, surnames to the Gagauzians. Relying mainly on data that lists various local figures gives us higher certanty that we are dealing with not deviating from the initial goal that this paper was meant to fulfill. The two works of Anatol Măcriș, namely Găgăuzii în diasporă și la ei acasă and Găgăuzii în literatura și publicistica română, provide us with lists of numerous local figures from Southern Moldova, acompanied by short description of their contribution to the communities in which they lived. Once the data was collected, the next step was that of revealing the exact ethimology of each name, the socio-linguistic context in which they are rooted, and possible "mutations" that may occurred over time from the struggle to balance the coexistence of different naming systems within one people group. As suggested earlier, this paper does not claim to provide results that are convertible in averages, the results are relevant for understanding how multi-centric naming systems can develop either through merging or layering.

We are attempting to generally highlight the root of the inherited names found among Gagauzians and the way in which they correspond to various virtues that are central to Gagauzians culture. It is important to state that we are not attempting to present the date in the form of patterns, to highlight the way in which the given name that were popular amongGagauzians prior to the colonization in Bessarabia were slowly replaced by Russian names. This is mainly due to the fact that the data that we have access to at the moment is quite insufficient in order for us to give such complex details.

The current paper is attempting to give a few reasonable answers to the following two questions:

Do the name-giving practices found among Gagauzians are more inclined toward conservatism, or are they opened toward novelties?

Which are the main virtues that are symbolically aligned with the given-names found among Gagauzians? 


\section{The Gagauzians: Between Romanian, Bulgarians and Folk-Orthodox costumes}

If we take a quick peek at the world, we will find that we actually deal with different naming systems, or criterias on which first/middle names and surnames are formed and atributed.The most common system is the patrilinear one, which maintains the continuity of sunrames across generations only through male descendents.

Besides this system, there are other systems, or we can simly call them costums, which give specific indications that need to be taken in to account when the parents decide the first and middle name that they will give to their new born child. The Romanians, or Vlach, as they were refered to in the old days, handed this responsability to the godparents. Or the child would receive the same names as, or a varion of, the name of one of the godparents - it is important to note that this costume had went out of fashion, and it is still kept alive, to a certain degree, in rural communities. Names that are rooted in the Christian tradition also see a decline in popularity among Romanians, young couples prefering to use names that are more exotic, or that of foreign origin but got naturalized. We should note that, unlike the Romanians living in Romania, Moldovans are more conservative when it comes to picking the names of their newborns. Even so, Moldovans tend to relying more heavly on Slavic loannames, this being dictated, of course, by the foreign rule, and regional influences, that deeply marked the Moldovan society (Măcriș, 2000).

Naming trends are often synonymous with a specific mindset that dominates a society at a given time, ethnic groups that developed within the borders or other states were more prone to adopt the trends of the dominating groups (Wang, 2015), or those groups that were present as the most influencial political actors within the state. It is still debated if the Gagazes could be labeled as an ethno-religious group, certain characteristics affiliated to this peoples indicate this posibility. First of all, more often than not, religion becomes the primary source of social normativity within ethno-religious groups. As a result, gradually, within these groups, religious faith slowly transitioned from an ideology that was supposed to be of divine inspiration, to a set of social norms that regulat everyday social affairs. This end-result has a very interesting outcome that we shouldn't ignore, it has mainly to do with the fact that as religion is downgraded to a framework of social norms there is a certain tendancy for the level of religiosity to gradually lower. Over a longer time spand, this can lead to the situation in which members of an ethno-religious group don't subscribe to the teachings of the religion itself, but rather are observing only those social norms and costumes that have their roots in certain religious practices, but were gradually downgraded to generally-used everyday costumes. Western scholars brought into discussion the concept of Folk-Christianity, as being a dominant element in the primitive Christian societies of Europe, being also present throughout the Middle Ages. FolkChristianity was later defined as well homogenized selection of cultural costumes that are liked, strongly or loosly, to various aspects of Christianity. This form of faith is more based of costumes and rituals, and dosen't pose a very big interest toward the more doctrinal aspects related to the faith. If we were to validate folk-Christianity as being a valid cultural framework on which various societies made their existance possible through the centuries, we must also acknowledge the fact that this trend of ,culturalizing" religion was directly responsable for the relative degree of religious illiteracy from various nations (Micu, 2012).

This could be also the case of the Gagauzians, as their Orthodoxy revolves more around folk costumes and rituals, rather than aspects linked to doctrine. Gagauzian Folk-Orthodoxyseverly influenced naming trends within the community. Self-identifying as devout Orthodox Christians, the Gagauzians set for themselves a very well outlined set of given names, thus limiting any substantial trans-generational variations when it came to naming trends. Mainly, the prefered given names were those of Orthodox saints, those that derived from them, fgures from folk legends and a more limited set of names that describe certain emotions, feelings or personality traits. If we take a look at the big picture, mainly Gagauzian trends for given name are really not that divergent from those associated with the Moldovan majority. By contrast to Romania, Moldovan and Gagauzian naming trends are more conservative and static in nature, also being more self-contained. Romania experienced an avalanche of Western given names, this being characteristic of the societies of the XX and XXI century. 


\begin{tabular}{lcccc}
\hline Romanian & Gagauz/Turkish & $\begin{array}{c}\text { Prefix/ } \\
\text { Composed }\end{array}$ & Sufix & Meaning \\
\hline Ciachir & Çakir & & & blue \\
\hline Cavarnali & Cavarnalı & & -li/-li & from Canvarna \\
\hline Colibaba & Kolibaba & Koli-Baba & & \\
\hline Cusursuz & Cursuruz & & & perfect \\
\hline Curudimov & Curudimov & & -ov & \\
\hline Caracioban & Karaçoban & Kara-Cioban & & black shepherd \\
\hline Tanasoglu & Tanasoğlu & Tanas-oglu & -oğlu & son of Tanas \\
\hline
\end{tabular}

Figure 1. Gagauzian surnames of Turkic origin (I)

It can be easily noted that patronymic surnames are present among the Gagauzians, they are usually indicated by the - oğlu (son of) termination. Patronymic surnames are not indigenous only to the Gagauzians, or only to Eastern Europe, they are present throughout the Old World, and on other continents as also. Even so, we can notice a certain degree of fluctuation when it comes to their presence among various groups of people. A main factor that could contribute to this can be related to the labor traditions from various regions, we can see that in the traditionally agricultural lands of Eastern Europe patronymic surnames have a high frequency, the same thing can be mentioned about Scandinavia. In both cases, the major economic activity was dominated by men laborers, in the fields of Eastern Europe, or if we are talking about the fishermen of Scandinavia.

\begin{tabular}{rcccc}
\hline Romanian & Gagauzian/Turkish & Prefix/composed & Meaning \\
\hline Papazoglu & Papazoglu & Papaz-oglu & $\begin{array}{c}- \\
\text { oglu }\end{array}$ & $\begin{array}{c}\text { son of the } \\
\text { bishop }\end{array}$ \\
\hline Sarioglu & Sariogli & Sari-oglu & $\begin{array}{c}- \\
\text { oglu }\end{array}$ & $\begin{array}{c}\text { son of the } \\
\text { blond man }\end{array}$ \\
\hline Fazlî̀ & Fazli & & $\begin{array}{c}\text { Ioachim } \\
\text { grape }\end{array}$ \\
\hline Ichimgi & Uzum & Uzum & & \begin{tabular}{c} 
irtuous \\
\hline
\end{tabular} \\
\hline
\end{tabular}

Figure 2. Gagauzian surnames of Turkic origin (II)

The data that was collected from various sources, mostly from a couple of ethnographic studies, displayed above in a more concise form, proves that the naming practices of the Gagauzians are not entirely divergent from those that can be found among the neighboring groups. First of all, it should be mentioned that Gagauzianonomastycs, by comparison to what we would find among some of the Slavs, is to a certain extent less patronymic, but it does not entirely lack names that solely describe ancestral affiliation. If we were to talk specifically about those names of Turcikorigin, we find some very interesting structures where the surname actually makes reference to both an ancestral profession, as the case with Çoban (lit. Sheppard), a trait, physical or moral. In most cases we are talking about a chromatic adjective, in an overwhelming number of cases Kara (lit. black) will appear. Kara appears quite often in both Turcik surnames, but it is also common within toponyms. Places as Qaraqalpaqastan, Kara Sea, Kara-Omer, Kara Deniz (Black Sea), Karakoi (Ro. Carachioi) exemplify the use of this chromatic adjective in an area that streches from the Russian Far North, to Central Asia and Romanian Dobrudja. Besides this, there are also other variations of surnames that combine references to personality traits and traditional professions - Delicoban (lit. crazy sheppard) is a good example, Deli- can also be found within the toponyms found along the south-western corner of Southern Dobrudja: Deliorman (lit. crazy forest) and Teleorman (Romanianized form).

A substantial number of Gagauzians inherited patronymic surnames, this specific segment of surnames is easy to identify as it is indicated by the suffix -oglu (lit. son). The way on which these surnames is formed is identical to what we encounter when dealing with English surnames, two parts: Proper name of 
the ancestor+suffix (-son), this way we have surnames as Johnson, Madison, Anderson etc. Among the Gagauzians, you will have Tanas + oglu - Tanasolgu (son of Tanas), Papaz+oglu (son of the Bishop). As it can be notices, there are samples in which the first segment is actually represented by a profession, and not a proper name. There are other cases in which the first segment is represented by references to physical traits combined with patronymc suffixes, the case of Sarioglu (lit. son of the blond man). It is quite difficult the way in which name came into being, but some hold certain characteristics that can link them to various cultural stages that the Gagauzians went through over the course of their settlement in Europe. Papazoglu in particular can be linked to the Gagauz settlers of Southern Dobrudja, these communities struggled for some time under the pressure of the Bulgarian Church which wanted them to go fully on their jurisdiction, even though, while they were living in DobrudjaGagauzianspreferred to attend Greek and Romanian parishes. This continued even in the early stages of colonization in Russian Bessarabia where Gagauzianspreferred that they parishes to be led by Romanian priests. As a result, it can be assumed that Papazoglu may actually refer to the expressed devotion that a particular family had toward a Greek or Romanian bishop, as for his role of messager of God on Earth. It may not actually link an actuallienage, but rather something more symbolic in nature. Surnames that indicate descendance from a particular place are indicated by the suffix $-l i$, as in Cavarnali (lit. Cavarnian,fromCavarna).

Some other TurcikGagauzian surnames include: Delicioban (lit. crazy shepherd), Kapsomun(lit. take the bread), Kioroglu (lit. blind man), Hagioglu (lit. son of the pilgrim), Terzi (lit. tailor), Kircioglu (lit. son of the man from the fields).Other surnames among the Gagauzians can include: Ghenov, Petrovic, Macovei, CervencovIvanciuc, Anantanasov.

This adds up to the list of common traits of name-giving practices vernacular to both Gagauzians and Romanians. Names as Bârlădeanu, Ardeleanu, Brăileanu, which indicated an affiliation with a city or region, are quite common among Romanians too, we can appreciate though that they have a more widely spread in the latter case. Another representative segment of Gagauz surnames can be traced to the Slavic languages. Even so, we cannot ignore some striking differences that exist between the way in which the names, that share a common origin, are latter shaped by each group. Radov, in the Eastern Slavic system this name would clearly be attributed to a male, this being indicated by the suffix -ov, and if it was attributed to a female the suffix would change to -ova. Within the same family with two children, the son would have his surname as Basov, and the daughter as Basova. This indicates that the suffix is gender sensitive, changing its form according to the gender of the name's owner. There is a slight difference when it comes to the functionalities of Slavic-loan surnames among the Gagauzians, it seems that the suffix lost its gender sensitive trait. This means that the surname holds on to the masculine suffix at any given context, so even if its owner is female the suffix will not change to -ova, remaining -ov (e.g. Elena Basov, Irina Radov).

\section{A few remarks on Gagauzian culture}

It would be foolish to think that we can paint a clear picture on the Gagauz by analyzing matters that relate primarily to names, toponyms and hidronyms. A crucial component is yet to be analyzed traditional clothing. It is important to acknowledge that the shape, ornamentation, and general aesthetic related to the traditional dress of these people was highly influenced by the different other groups that they came in contact with over time. The traditional dress of the Gagauz blends in with the general aesthetic that dominates Romania's Lower Danube region, and if we were to thing even in a more nuanced manner, to the traditional dress of Southern Dobrudja. Romanian ethnologists had highlighted over the last few decades that similarities between the traditional wear of the people that reside in the areas which border the segment of the Danube that flows from Călăraşi (south) to Galaţi (north), The Lower Danube, which encompasses the southern counties of Moldavia, all of Dobrudja, and the western portion of Wallachia, is strongly characterized by a culture that is centered around rural life and agriculture. As a result, the traditional dresses that was wore in day-to-day life was quite modest, being solely meant to be rather functional, than pleasing to the eye (Ielenicz, 2005).

The dress that was displayed on special occasions was more spectacular, the most eye-catching piece being the apron, which featured a complex network of brightly colored geometrical motives. The Gagauz of Southern Dobrudja were involved in agriculture and fishing (Michalopoulos, 2016). As with the Romanians and Bulgarians, it is also noticeable among Gagauzian striking differences between festive and day-to-day clothing. Festive clothing is more eye-catching, and heavily centered around chromatic contrasts, bright colors, and accessories made from precious metals. In daily life, the women's dress is much more discreet, the colors usually tend to be more toned down and the usage of grey, brown, or dark colors is not unusual. While in the few surviving Gagauz communities that are scattered across the north-east of historic Rumelia 
the highly ornate aprons were well preserved. The line of the dress line of the traditional dress of the Moldovan Gagauzian took a different path thou, nowadays it resembles more the basic features of the traditional Bulgarian 'household dress'(Baltsiotis, 2014). This would not come as a surprise, the two sides have a long history of interaction, as a result of evolving the in proximity of each other. Both sides benefited from the policies carried of the Russian Empire in the early XIX century for repopulating Budjak and those areas which lay within the borders present-day southern Moldova (Genov, 2010). The Gagauz dress seems to be a reinterpretation of the common wear of Bulgarian women, with some slight differences when it comes to accessories (Ullah, 2016). It is not uncommon for people that reside in colonies to stress functionality and pragmatism more than aesthetics, we are not suggesting that the later fades away completely, but the gap between the two is narrowed considerably. Ethnologists pointed out that most of the household tools and technology used by the Gagauz of Budjak and Moldova was mainly borrowed from groups from their proximity, this being the case as a result of a lack of initiatives toward designing technological solutions for simplifying daily chores from within the group (Balázs, 2003).

As their Bulgarian and Romanian counterparts, the Gagauz also exhibit traces of a 'carpet culture'. Carpets, especially those used for decorative purposes, are regarded as a hallmark of Gagauz textile craftsmanship, women being solely responsible for weaving the carpets that will adorn the interiors.

\section{The Gagauzians as part of a Dobrudjan Diaspora}

Some scholars had stated several times that the Gagauzians were directly responsible with the creation of one the only few non-Slavic Orthodox tradition that is worth mentioning, it should be taken into account that besides this group there are a few other Turcik nationalities that adhere to Orthodox Christianity, as is the case with the Orthodox Turks that reside nowadays in Greek Thrace, their homeland being Anatolian heartland. Other notable mentions are the Chuvash of the Middle Volga, and to a certain extent, the Yakuts of Eastern Siberia, even though the indigenous communities of Siberia that adopted Orthodoxy during the area of Russian settlement still heavily mix in various practices that are routed within the belief systems that mainly have to do with Shamanism than with Christianity. From a purelynumerical perspective, the Orthodox Turciknationalities of Russia heavily outnumber both the Gagauzians of Moldova and the Orthodox Turks of Greek Thrace. What makes the Gagauzians, Thracian Turks and Chuvash quite unique in the sense that Orthodoxy is fully assimilated within the group's culture, thus influencing various segments of social life. Groups like the Dolgans and the Yakuts mainly perceive Orthodoxy as a vital link between themselves and the Russian state, which has its core around centers such as Moscow and Saint Petersburg. In their particular case, Orthodoxy doesn't take the actual role of a set of beliefs that would regulate various social spheres, it actually takes the role of a label that acknowledges, to a certain extent, the group as being integrated within the realm of Russian culture, even though even here they hold on to a marginal position (Yenisoy, 2015). When discussing about the indigenous peoples of Siberia, we can easily point out a shell-like religious identity (Ahmed, 2016), in which the core, represented by ancestral shamanistic practices managed to preserve itself almost intact, and an outer shell that is made up of a purely superficial Orthodoxy, that does not fill any spiritual role, mainly. There are cases of indigenous families that abandoned their traditional nomadic lifestyle as a result of settling in various urban centers, in this case there is a higher probability that they will start having a more authentic outlook on Orthodox spirituality, due to the fact that they feel a greater pressure of the culture of the Russian majority.

Even so, it would be foolish to think that within the worldwide Orthodox Church there is a unitary standard when it comes to ritual and tradition, there is a strong canonical core which regulates various aspects related to ritual and worship, but there are also a lot of differences that are the result of linguistic differences, or some aspects that are more dictated by local traditions. Nowadays, talking strictly about the Gagauzians of Moldova, their commonly shared practices concerning ritual and worshiped have deeply morphed during the last few generations. During the period of settlement in Dobrudja, Gagauz spirituality was deeply influenced by that of the Greels, Bulgarians and Romanians (Hatłas, 2011). Numerous groups of Bulgarians and Gagauzians from Ottoman Dobrudja started settling on the valley of the Ialpug rivers, present-day Moldova and Ukraine, beginning with the first decade of the XIX century. In this region Gagauzians and Bulgarians formed mixed communities, repopulating some of the villages that were left deserted by the Nagoy Tatars that flee the region after it was annexed by the Russian Empire. A few other groups came to the newly-annexed territory, a few groups Greeks made their way to Besserabia, but stayed for a very short time, shortly after making their way in to Dobrudja, where along with a few families of Bulgarian that came with them became the founders of the village of Alibeichioi (Izvoarele). 
Because of their short stay in Besserabia among Bulgarians and Gagauzians, the Greeks from Constanta often identify them as being either Bulgarians or Gagauzians, questioning their Greekness due a history of mixed marriages that occurred between them and the other two mentioned groups. After settling on the Ialpig valley, new parishes were created within the new communities. The churches that were built during this period were in Muscovy Baroque, a style that combines elements native to traditional Russian Architecture and elements of the Baroque style.

Through the analysis of the various traditional clothing styles, motifs and jewelry, we can outlines a "corridor" that begins in Southern Dobrudja (Bulgaria), and extends all the way through the coastal counties and Constanta and Tulcea (Romania), and has its northernmost extremity in Moldova's Autonomous Region of Gagauzia, The Dobrudjan Corridor is not defined as a territory that can be characterized by any degree of physical or geological homogeneity, the plains and wetlands that stretch north of the Danube heavily contrast with the rocky valleys and inselbergs that are scattered through Northern Dobrudja. This region is brought together by a number of ethnographic characteristics, this is clearly noticeable when it comes to the material heritage of many people groups from this area. The beginning of the XIX century was marked by a massive colonization of two main Dobrudjan groups - Gagauzians and Bulgarians, the logical outcome was the crystallization of a Dobrudjan diaspora. The traditional dresses found among the Romanian and Bulgarians of Northern Dobrudja are extremely similar both when it comes to their style and the techniques used to manufacture them with those traditional dresses that make up the current-day ancestral heritage of the Gagauzians and Bulgarians from Gagauzia, Cahul and the territory of the historical Budjak. The aprons that were wore by Gagauzian women during various holidays are based on the same geometric structure as the ones wore by the Romanians of Dobrudja - rectangular in shapes with two richly ornate borders on both sides, the central segment usually contains scattered rhomb-shame motifs, the bottom half of this segment can be dominated by a zig-zag pattern. Apron styles such a "grădinile" (the gardens) and "ceidoisori" (the two suns) can be found both among the Gagauzians that live north of the Danube and the indigenous Romanians of Dobrudja. Other commonly-shared elements related to the traditional dress are:gearul cu topi - a long head scarf that has its border made up of long fringes - it comes in white, black and yellow, it is similar to a particular style of Russian headscarf which Romanian refer to as broboadă, but this later one is longer, hanging way over the shoulders; golden coin necklaces- common to women, they were a symbol of wealth, thus usually found among women that came from prominent families. Gagauzian women would receive a salbă as a wedding gift from the groom's family, another one she would inherit from her family; flower as a symbol of youth-Gagauzian, Bulgarian and Romanian women often put on display red flowers as a means of accentuating their youth, most common among unmarried girls. Flowers, as an integral item of the traditional dress, was not so popular among older women, but when this was the case the preferred flower was not red, due to the fact that this particular color was reserved for the youth.

\section{Conclusion}

The study of Gagauzian onomastics is highly sensible when it comes to impact of a few keyhistorical events had on the evolution of this group, by this we are referring to the fact that trends in name giving were deeply influenced by the historical and political context that dominated a certain epoch. Also, Gagauzian onomastics have a complex structure, as a result of the fact that the sources are rooted in a few different cultural traditions. Nonetheless, this group of people managed to maintain a very good selfawareness, there are no historical sources that indicate that the Gagauzians themselves were questioning their own identity, but rather there was a certain degree of confusion that came from outsiders; When it comes to the actual content, Gagauzian onomastics present us a rich variety of naming practices, both in the case of given names, and in that of surnames. As a general note, it can easily be observed that many surnames are patronymic in nature, and many given names try to highlight the group's devotion to Orthodox Christianity, most newly-born receiving names honoring various saints;

Through the close contact that the Gagauzians had with other groups, mainly Bulgarians, Romanians and Russian, they inherited various cultural elements that enriched their culture over times. Due to the close contact that this group had with various non-Turcik Christian groups, their culture resembles more that of the South Slavs and Romanians, mainly, than that of other Turkic groups from the Balkans and Eastern Europe, that are of Islamic faith. There is still a certain degree of debate on whether or not Gagauzians can be labeled as an ethno-religious group. This discussion mainly derives from the fact that Orthodox Christianity represented a defining element that set aside the Gagauzians from other Turcik groups from the Balkans and Eastern Europe. Orthodoxy itself shaping the way in which this group later associated itself with other groups, made alliances and formed political ideals; 
As a result of the historical events that unfolded over the last two centuries, present-day Gagauzians heavily identify themselves with Eastern Europe, as a cultural motherland. Even so, ties with Turkey are becoming much more of a bigger interest now, then they were in the past, for the authorities from Comrat. In order to achieve and in depth understanding on the development of multi-centric naming systems we need to truly understand the particularities attached to the systems that the Gagauzians came in contact with over the course of time and gradually adapted to fir their own cultural context. We should never start a study involving this subject with a question like "Which names are truly Gagauzian?", but rather which is the order in which they align themselves in the greater framework of the naming practices.

The current study has as a main goal that of opening a discussion in regard to the correlation between onomastics and culture, or the way in which names can act as markers (descriptors) of a culture's dynamics over time. Even if, at least in Romania, there was an important scientific event solely dedicated to the research of onomastics, held in Baia Mare, this is quite insufficient. To this day, onomastics were mainly sought after as a research subjects by linguists, which is quite understandable to a certain extent. But, we must understand that onomastics can be also researched by cultural anthropologists in their attempt to give an accurate display of a group's social patterns, and more precisely interactions with outsiders, over the course of decades and centuries. Onomastics can give us valuable date in regard to a group's integration, or segregation, in the wider society; it can also show us how much a group is inclined toward the self-preservation of its own identity, mostly coinciding with a traditionalist outlook, and how much it is opened toward cultural novelties.

||This paper seeks to stimulate academic discussion that involve the overlap between cultural dynamics and onomastics, if our data is sufficient when attempting to do such studies, which are usually reliant on birth/marriage/death records that are usually kept within the archives of townhalls, we can easily determine those patterns that are corelated to groups cultural history. A good example in this case is represented by the general naming practices that were popular among Gagauzians prior and after their settlement into the Russian Empire. We can easily notice that Russian given-names increased in popularity among the Gagauzians that settled in Russian Bessarabia, but it is hard for us to determine the pace in which these names slowly replaced those that were dominant before this era.

We can conclude that Gagauzian name-giving practices never put too much emphasis on the origin of the name that a newborn received, but rather on the way the key-virtues commonly held by the peoples were symbolized through them. If we were to talk about surnames, things are little bit more complicated, taking into consideration the fact that one could not decide upon his/her surname. Even so, one thing that is clear when it comes to surnames is that they finely reflect the way in which Gagauzians interacted, and came under the rule of various empires. Each society in which Gagauzians lived throughout the centuries had its own specific set of cultural mechanism which had the purpose of creating social order, as a result, Gagauzians conformed to this, especially in those moments in which hostilities toward minorities were more prevalent.

\section{Acknowledgement}

It should be taken into account that the data that was collected, and subsequently included in this paper, is not able to gfreive realiable facts regarding the percentage of people that share some of the names that are listed. Giving procentual data regarding the frequency of certain name was never the main goal of this paper, rather what we tried to do is to describe the naming practices that are in use among Gagauzians, the origin and spacial distribution in Gagauz-inhabited area of certain names. A study regarding the exact frequency of various given names and surnames is hard to develop in the absence of reliable records and surveys which include a represenative segment of the group that is set to be studied.

\section{References}

Ahmed, M. (2016). Ethnicity, identity and group vitality: A study of Burushos of Srinagar. Journal of Ethnic and Cultural Studies, 3(1), 1-10.

Aydin, H., \& Koc-Damgaci, F. (2017). From empire to republic: Citizenship, pluralism, and diversity in Turkey. In James, A. Banks (Eds.), Global migration, structural inclusion, and education across nations. Washington, DC: American Educational Research Association (AERA) Press.

Bas, A. I. (2015). Demographic engineering: Bulgarian migrations from the Ottoman Empire to Russia in the nineteenth century. Ankara, Turkey: Bilkent University.

Damgaci, F. K., \& Aydin, H. (2014). An analysis of academicians' perceptions of multicultural education: A Turkish experience. The Anthropologist, 18(3), 817-833. 
Duminică, I. (2016). "Monografiile” comunelor plasei Comrat, județul Tighina din 1943[Monographs "of the Comrat area communes, Tighina County in 1943]. Journal of Ethnology and Culturology, 21, 102105.

Duminică, I. (2017). Istoria unei fotografii din satul Beșalma-Comrat [The history of a photo in the village of Besalma-Comrat]. This paper is presented at the International Scientific Conference on Cultural Heritage in Kishinev.

Genov, N. (2010). Radical nationalism in contemporary Bulgaria. Review of European Studies, 2(2), 5-7. Haltas, J. (2011). The Gagauz people in Bessarabia.Poznan, Poland. Stupskie History Studies, 17. 191-199.

Ielenicz, M. (2005). Physical geography of Romania. Retrieved from http://romaniatourism.com/geography.html

Iulian, I. M. (2017). Indigenous Heraldry: Transferring ethnic imagery from the mundane to the canonical. Journal of Ethnic and Cultural Studies, 4(1), 26-33.

Kaya, Y. (2015). The opinions of primary school, Turkish language and social science teachers regarding education in the mother tongue (Kurdish). Journal of Ethnic and Cultural Studies, 2(2), 33-46.

Măcriș, A. (1999). Găgăuzii. Buchare, Romania. Agerpress, 2, 20-25.

Măcriș, A. (2003). Găgăuzii din Basarabia între trecut și prezent [Gagauz fromBessarabia between past and present]. Bucharest, Romania: Agerpress Typo Press.

Măcriș, A. (2007). Găgăuzii în literatura și publicistica română [Gagauz in Romanian literature and journalism]. Retrieved from http://www.galeriile-cismigiu.ro/gagauzii-in-literatura-si-publicisticaromana-p16154

Michalopoulos, D. (2016 January). The metropolitan of the Gagauz": Ambassador Tanriöver and the problem of Romania's Christian Orthodox Turks. This paper is presented at the International Balkan Annual Conference (IBAC), Constanta, Romania.

Micu, I. (2012). Constantin Brătescuşicercetareatrecutului Dobrogei [Constantin Bratescu and the research of Dobrogea's past]. Retrieved from https://revistapontica.files.wordpress.com/2012/03/pontica-4-pag-9-20.pdf

Trencsényi, B. (2003). Peasants into Bulgarians, or the other way round: The discourse of National Psychology. Retrieved from https://pasts.ceu.edu/sites/pasts.ceu.edu/files/basic_page/field_attachment/peasantsintobulgarians.p df

Ullah, A. (2016). Understanding perceptions about the role of traditional practices regarding inheritance with relation to Inheritance Feud Settlement: A case study of District Mardan Khyber PakhtunkhwaPakistan. Journal of Ethnic and Cultural Studies, 3(2), 1-9.

Wang, T. (2015). Marginality of rural migrant students in eleven Chinese high schools. Journal of Ethnic and Cultural Studies, 2(2), 21-32.

Yenisoy, H.S. (2015). On the Turkish dialects in Bulgaria and their Bulgarian loanword. International Sciencetific Online Journal, 7, 28-41. 


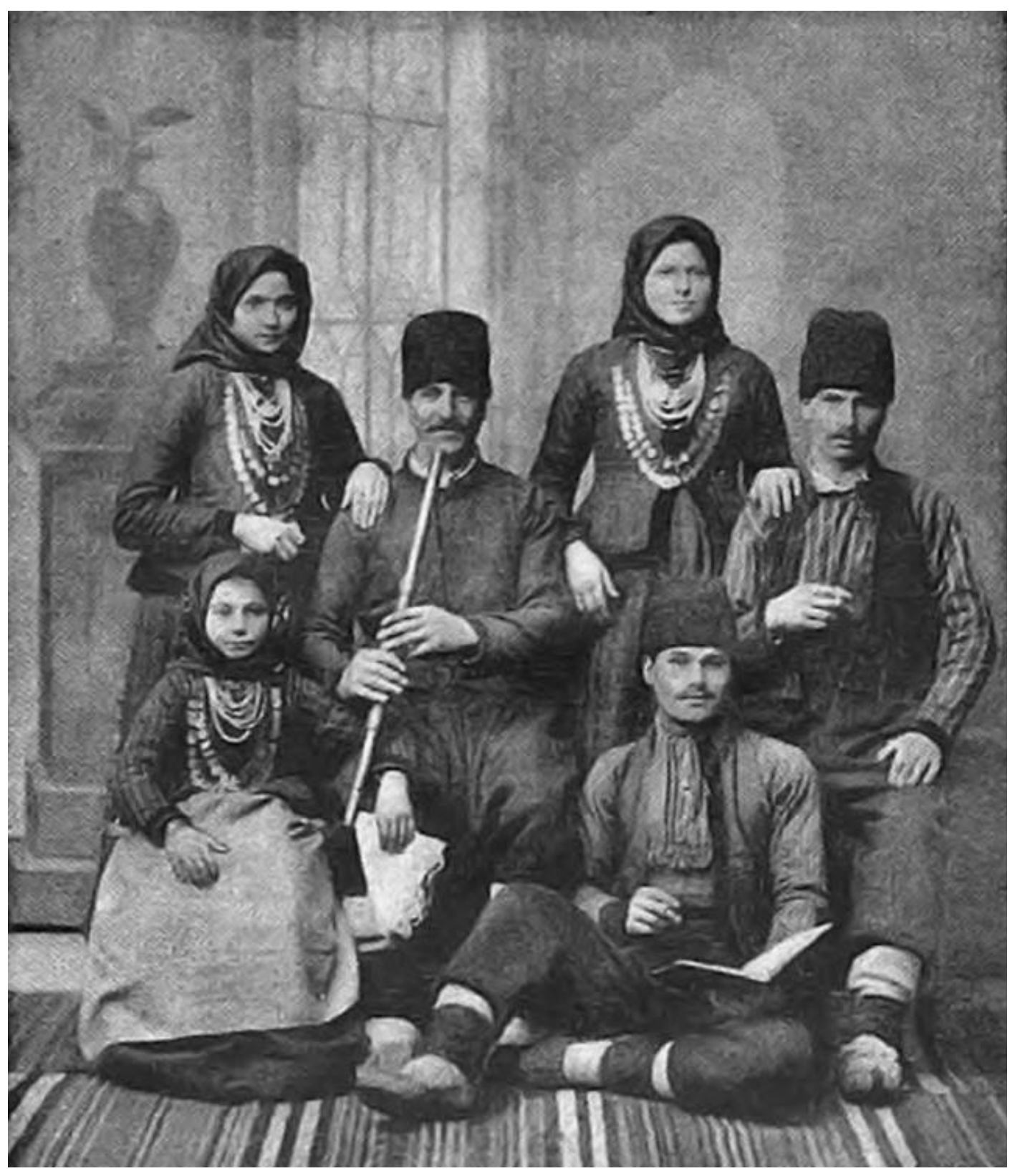

Figure 3.Family of prominent Gagauzians from Moldova (source: MihailCiachir Library) 